\title{
The Effect of Brand Personality of Electronic Word of Mouth on Wardah Products with Brand Preference as an Intervening Variable
}

\author{
Yunita Engriani ${ }^{1}$, Gadiesha Dina Aulia ${ }^{2}$ \\ ${ }^{1}$ Universitas Negeri Padang, Padang, Indonesia, $\square$ yunitaengriani@gmail.com \\ ${ }^{2}$ Universitas Negeri Padang, Padang, Indonesia, $\square$ gadiesha.dinaaulia@gmail.com
}

\begin{abstract}
This study aims to analyze (1) the influence of brand personality on electronic word of mouth, (2) the influence of brand personality on brand preference, (3) the influence of brand preference on electronic word of mouth, and (4) the influence of brand personality on electronic of mouth through brand preference as an intervening variable.This type of research is causative research. The population of this research is all users of wardah products. While the number of research samples is determined based on the purposive sampling method. The sample is 150 people. This study analyzed the data using Structural Equation Modeling (SEM) with Smart PLS 2.0 software.The results of this study indicate that: (1) brand personality has a positive and significant effect on electronic word of mouth, (2) brand personality has a positive and significant effect on brand preference, (3) brand preference has a positive and significant effect on electronic word of mouth, (4) brand personality has a positive and significant effect on electronic word of mouth through brand preference as an intervening variable.
\end{abstract}

Keywords: Brand personality, electronic word of mouth, brand preference

\section{Introduction}

Cosmetics is currently a major requirement for some women, especially modern women, to support each of their activities as part of their self-image. The increasing need for cosmetics is partly due to the increasing number of women working outside the home. This was supported by data from the Central Bureau of Statistics (BPS), the percentage of female formal labor in 2015 was $37.78 \%$, in 2016 it was $38.16 \%$, and in 2017 it increased to $38.63 \%$ (https://www.bps.go.id/).

Information above is supported by data on the growth of the cosmetic industry in Indonesia released by the Ministry of Industry in 2018, the cosmetic industry in Indonesia in 2017 grew by $6.35 \%$ and increased to $7.36 \%$ in the first quarter of 2018. Throughout 2018, the cosmetics industry is estimated to grow by $7.33 \%$ (https://m.bisnis.com).

Cosmetics manufacturers that sell their products in Indonesia have been very diverse, ranging from foreign products and local products. There are various kinds of local brand cosmetic products that are currently in demand by consumers. In Indonesia there are several quality local brands such as Sariayu, Wardah, Make Over, Purbasari, Mineral Botanica, Emina, and Viva (source: https://www.fimela.com).

Today, halal is not only considered for food and drink, but also the halal cosmetics used. Because more and more Indonesian people are starting to care about cosmetics that are halal-certified, then more and more local products are selling halal-certified cosmetics.

One local product that already has halal-certified cosmetics is Wardah. Wardah is a pioneer in creating halal-certified beauty products, sharing a new understanding that halal ways of life and beauty products are able to blend elegantly (source: https://paragon-innovation.com/brands/). 
Table 1 Cosmetics Halal Certified 2018

\begin{tabular}{clcl}
\hline Number & \multicolumn{1}{c}{ Name } & Number & \multicolumn{1}{c}{ Name } \\
\hline 1 & BLP by Lizzie Parra & 14 & Moko-Moko \\
\hline 2 & Caring & 15 & Mustika Puteri \\
\hline 3 & Emina & 16 & Mustika Ratu \\
\hline 4 & Garnier & 17 & PAC \\
\hline 5 & L'Oreal & 18 & Pixy \\
\hline 6 & LT Pro & 19 & Purbasari \\
\hline 7 & Make Over & 20 & Pond's \\
\hline 8 & Marina & 21 & Red-A \\
\hline 9 & Martha Tilaar & 22 & Sariayu \\
\hline 10 & Marcks & 23 & Viva \\
\hline 11 & Mazaya & 24 & Wardah \\
\hline 12 & Mineral Botanica & 25 & Zafra Miracle \\
\hline 13 & Mirabella & 26 & Zoya Cosmetics \\
\hline
\end{tabular}

Source: https://halalcorner.id

From the data above, it can be seen that in Indonesia, besides Wardah, there are some cosmetic brands that already have halal labels. This certainly makes consumers confused to choose which products they should buy. According to Setiadi (2003) there are several stages of consumers before making a purchase, including recognizing needs, seeking information, evaluating alternatives and purchasing decisions.

With the development of technology, information seeking is now very easy to do, namely through internet media. Today, the internet is the most frequently used media of information. Information seeking can be done through, websites, blogs, social media such as Twitter, Facebook, Instagram and YouTube. Access to information through the internet is better known as Electronic Word Of Mouth.

Electronic WOM is defined as "any positive or negative statement made by a prospective customer, actual customer, or ex-customer about a product or company that is available to many people and institutions through the internet" (Hennig-Thurau et al., 2004).

After searching for information from the internet that's where consumers get what product preferences they will buy. Preference is the tendency for something that is usually obtaineder consumers compare a product with another product. Brand preference is the tendency of consumers to like a brand compared to others so that it will shape their desire to buy the brand.

Consumer preference is also based on the consumer personality. According to Aaker (1997) brand personality is defined as a series of human characteristics associated with a brand. Brand personality can be used as a way to differentiate brands from competitors (Aaker 1997).

The emergence of the internet has expanded consumers' choices to gather unbiased product information from other consumers and provide opportunities for consumers to offer advice regarding the products they consume themselves by engaging in electronic word of mouth (Hennig-Thurau et.al, 2004). Electronic WOM is defined as "any positive or negative statement made by prospective customers, actual customers, or former customers about a product or company that is available to many people and institutions through the internet" (Hennig-Thurau et al., 2004).

Based on the research of Su et al., (2016), there are several indicators of word of mouth as follows:

1. Give positive comments

2. Recommend brands to others

3. Refer brands to others 
According to Aaker (1997), brand personality is defined as a set of human characteristics associated with a brand. According to Rangkuti (2004) in his book The Power Of Brands, said that to differentiate products produced from competing products, companies make additional personal values on each brand, the difference between customers and brands is getting smaller because the brand has shown characteristics more personal so that consumers feel more personal. In brand personality, the brand is a reflection of personality, the function of the brand is not just an illustration of the product, but the brand is the personal representative of the user.

Jennifer L. Aaker (1997) suggests that brand personality has dimensions designed to describe the structure and nature of brand personality. The five dimensions are known as "The Big Five" as follows:

1. Sincerity: Down to earth, honest, wholesome, cheerful

2. Excitement: daring, spirited, imaginative, up to date,

3. competence: reliable, intelligent, successful

4. sophistication: upper class, charming

5. ruggedness: outdoorsy, tough

According to Upamannyu, Nischay, K. et al. (2014), brand preference refers to a measure of brand loyalty where consumers will choose a particular brand before a competing brand, but will receive a replacement if the brand is not available. Chomvilailuk, et al. (2010) in (Kedhi, 2014) define brand preference as everything where consumers prefer brands of a product based on their first experience in using the brand compared to other similar brands. According to Rangkuti (2004) in his book The Power Of Brands, said that the customer characteristics of a brand preference, namely customers have compared various kinds of products from other companies based on the consistency of the quality of the products produced. Thus, the strategy of the company is to provide the right brand with the superiority of the product that is owned so that it is difficult to imitate the competitors. To keep the brand from being copied, the brand is patented to get a registered brand.

According to Chen (2008) as for consumer preferences for a particular brand compared to other brands can be measured by the following statement:

1. Attractive product brands

2. Brand products are preferred

3. Product brands are more desirable

4. Product brands are preferred as a whole

In research Wahyuningtyas (2016), argues that brand personality can shape the communication process in consumers because it provides convenience to consumers in identifying brands, so brand personality can provide distinctive features and pride because of a product they have. This will affect consumers to retell to friends or family about the characteristics of a product used.

In the study of Kim et al. (2011) say the concept of self-conformity states that consumers prefer brands that are known for the same characteristics as their own personalities. As a result, brand personality can serve as a mechanism to differentiate brands and can function as the main determinant of consumer preferences and use.

In Satvika's research (2013) said brand preference is very dependent on customer experience. In other words, positive customer experience directs customers to choose a particular brand (Hellier et al, 2003, in Satvika 2013). The attitude of consumers comes from evaluating brands after consuming certain products or services. Thus, a positive attitude towards a restaurant brand is a result of satisfaction with a particular brand of product or service, which means there is a possibility that customers prefer a particular brand of product or service compared to other brands (Satvika, 2013).

The results of the study by Kim et al. (2011) which examined two restaurants said that brand personality perceptions influence WOM behavior through the mediating effects of brand preference and brand loyalty attitudes (i.e. for both restaurant chains, perceptions of brand personality displayed significant causal relationships between each these process variables are interventions that are directly affected by WOM behavior). 


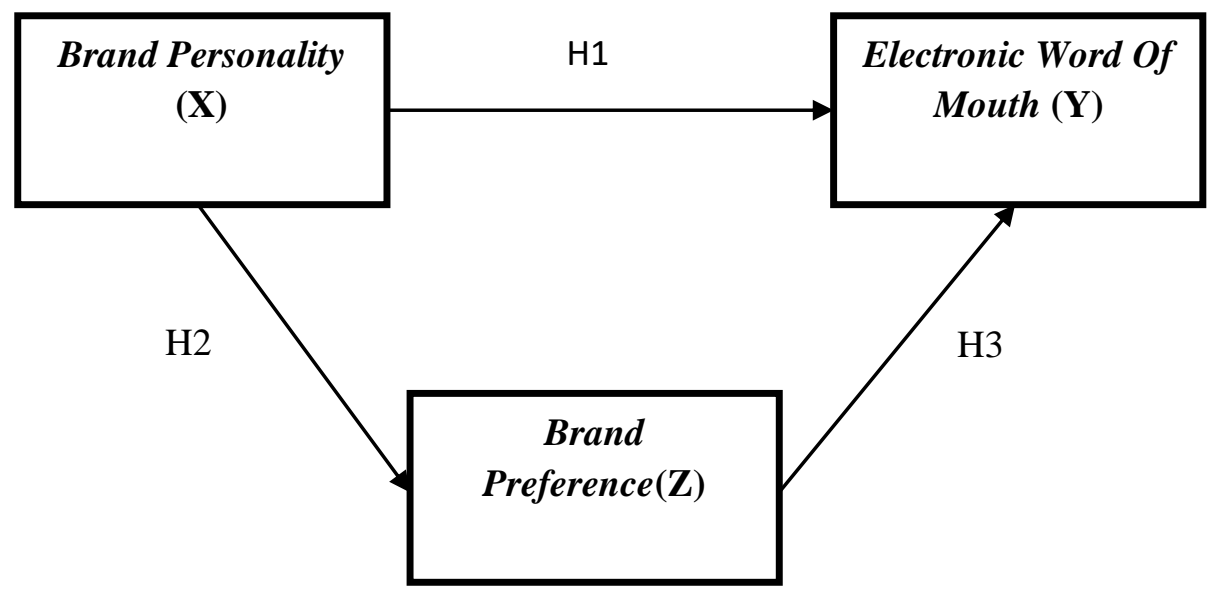

Figure 1 Conceptual Framework

H1: Brand Personality has a significant effect on Electronic Word Of Mouth on Wardah Products in Padang City

H2: Brand Personality has a significant effect on Brand Preference on Wardah Products in Padang City

H3: Brand Preference has a significant effect on Electronic Word Of Mouth on Wardah Products in the City of Padang

H4: Brand Personality has a significant effect on Electronic Word Of Mouth on Wardah Products in the City of Padang through Brand Preference as an intervening variable

\section{Methods}

This research is a type of survey research, namely by collecting data and information to obtain facts and information about this study from respondents using a questionnaire, where the questionnaire contains several structured questions answered by respondents related to brand personality, electronic word of mouth and brand preference. The sampling technique of this study was purposive sampling, with criteria namely: Individuals who have already purchased Wardah products that are at least 17 years old and have social media accounts.

The amount of the research sample based on the Cochran formula is as follows:

$\boldsymbol{n}=\frac{z^{2} p q}{e^{2}}$, with a standard allowance of $8 \%$, so that the following results are obtained, $\mathrm{n}=150.06$.

Then a sample of 150 respondents was obtained.

\section{Results and Discussion}

\section{Test Validity and Reliability}

Based on table 2, it can be seen that all statements have an outer loading value $>0.6$, which means all of these statements are valid. So based on the results of testing AVE and outer loading to test the convergent validity declared valid. 
Tabel 2 Validity and Realibity Test Results

\begin{tabular}{|c|c|c|c|c|}
\hline Variable & Numbetr & Indicator & $\begin{array}{c}\text { Outer } \\
\text { Loading } \\
(>0.6)\end{array}$ & AVE \\
\hline \multirow[t]{13}{*}{ Brand Personality (X) } & 1 & $\mathrm{BP} 1$ & 0.792 & 0.746 \\
\hline & 2 & $\mathrm{BP} 2$ & 0.844 & \\
\hline & 3 & BP3 & 0.863 & \\
\hline & 4 & $\mathrm{BP} 4$ & 0.875 & \\
\hline & 5 & BP5 & 0.885 & \\
\hline & 6 & BP6 & 0.871 & \\
\hline & 7 & BP7 & 0.887 & \\
\hline & 8 & BP8 & 0.839 & \\
\hline & 9 & $\mathrm{BP9}$ & 0.881 & \\
\hline & 10 & $\mathrm{BP} 10$ & 0.880 & \\
\hline & 11 & BP11 & 0.884 & \\
\hline & 12 & BP12 & 0.860 & \\
\hline & 13 & $\mathrm{BP} 13$ & 0.862 & \\
\hline \multirow[t]{4}{*}{ Brand Preference (Z) } & 14 & BPR1 & 0.874 & 0.815 \\
\hline & 15 & BPR2 & 0.919 & \\
\hline & 16 & BPR3 & 0.908 & \\
\hline & 17 & BPR4 & 0.910 & \\
\hline \multirow{4}{*}{$\begin{array}{c}\text { Electronic Word Of } \\
\text { Mouth (Y) }\end{array}$} & 18 & EWOM1 & 0.877 & 0.777 \\
\hline & 19 & EWOM2 & 0.859 & \\
\hline & 20 & EWOM3 & 0.887 & \\
\hline & 21 & EWOM4 & 0.901 & \\
\hline
\end{tabular}

Tabel 3 Variabel Correlations

\begin{tabular}{lrrr}
\hline \multicolumn{1}{c}{ Variabel } & $\begin{array}{c}\text { Brand Personality } \\
(\mathbf{X})\end{array}$ & $\begin{array}{c}\text { Brand Preference } \\
(\mathbf{Z})\end{array}$ & $\begin{array}{c}\text { Electronic Word } \\
\text { Of Mouth (Y) }\end{array}$ \\
\hline Brand Personality (X) & 1.000 & 1.000 & \\
\hline Brand Preference (Z) & 0.919 & 0.805 & 1.000 \\
\hline Electronic Word Of Mouth (Y) & 0.791 & & \\
\hline
\end{tabular}

Based on table 3 above it can be seen that the value of the square root AVE is greater than the other constructs. This shows that all constructs in this research model have met the specified discriminant validity.

Tabel 4 Composite Reliablity dan Cronbachs Alpha

\begin{tabular}{lcc}
\hline & $\begin{array}{l}\text { Composite } \\
\text { Reliability }\end{array}$ & Cronbachs Alpha \\
\hline Brand Personality (X) & 0.974 & 0.972 \\
\hline Brand Preference (Z) & 0.946 & 0.924 \\
\hline Electronic Word Of Mouth (Y) & 0.933 & 0.904 \\
\hline
\end{tabular}

Based on Table 4, it can be seen that the value of Cronbachs alpha and composite reliability of each construct exceeds 0.7. This is in accordance with the rule of thumb, the value of cronbachs alpha and 
composite reliability must be greater than $0.7(>0.7)$ respectively, so the instrument from this study can be declared reliable.

Table 5 Test Inner Model

Tabel 5 R-Square

\begin{tabular}{lc}
\hline & R-Square \\
\hline Brand Preference (Z) & 0.844 \\
\hline Electronic Word Of Mouth (Y) & 0.665 \\
\hline
\end{tabular}

The table above illustrates that the value of R-Square for electronic word of mouth variable is 0.665 . This indicates that $66.5 \%$ of electronic word of mouth variables can be influenced by brand personality variables, while $33.5 \%$ are influenced by other factors. Next, the R-Square value for the brand preference variable is 0.844 . This indicates that $84.4 \%$ of brand preference variables are influenced by brand personality, while $15.6 \%$ is influenced by other factors.

Tabel 6 Path Coefficients

\begin{tabular}{lccc}
\hline & $\begin{array}{c}\text { Original } \\
\text { Sample (O) }\end{array}$ & $\begin{array}{c}\text { T Statistics } \\
(\mid \mathbf{O} / \text { STERR } \mid)\end{array}$ & $\begin{array}{c}\text { Tinjauan } \\
\text { Hipotesis }\end{array}$ \\
\hline B. Personality -> EWOM & 0.330 & 2.021 & Diterima \\
\hline B. Personality -> B. Preference & 0.919 & 51.94 & Diterima \\
\hline B. Preference $>$ EWOM & 0.501 & 2.993 & Diterima \\
\hline B. Personality -> B.Preference -> EWOM & 0.46 & 2.987 & Diterima \\
\hline
\end{tabular}

\section{Hypothesis 1}

Based on the analysis of brand personality variables positive and significant effect on Wardah electronic word of mouth products. This is evidenced by the calculation results obtained by the path coefficient value of 0.330 with $t$ count of 2.021. This value is greater than $t$ table 1.96 . This result means that there is a significant and positive influence between brand personality and electronic word of mouth.

The results of this study are in line with the research conducted by Wahyuningtyas (2016) which states that brand personality has a significant effect on word of mouth. Wahyuningtyas (2016) argues that brand personality can form a communication process for consumers because it provides convenience to consumers in identifying brands, so brand personality can give distinctive features and pride because of a product they have. This will affect consumers to retell to friends or family about the characteristics of a product used.

\section{Hypothesis 2}

Based on the analysis of brand personality variables has a positive and significant effect on Wardah's brand preference. This is evidenced by the calculation results obtained by the path coefficient value of 0.919 with $t$ count of 51.940. This value is greater than $t$ table 1.96. This result means that there is a significant and positive influence between brand personality and brand preference.

This study has similarities with Kim's (2011) research which suggests that brand personality has a significant effect on brand preference. In the study of Kim et al. (2011) entitled "The effects of customers' perceptions of brand personality in casual theme restaurants" suggest that brand personality has a significant effect on brand preference. Kim (2011) said the concept of self-conformity states that consumers prefer brands that are known for the same characteristics as their own personalities. As a result, brand personality can serve as a mechanism to differentiate brands and can function as the main determinant of consumer preferences and use. 


\section{Hypothesis 3}

Based on the results of the brand preference variable analysis positive and significant effect on Wardah electronic word of mouth products. This is evidenced by the calculation results obtained by the path coefficient value of 0.501 with $t$ count of 2.993. This value is greater than $t$ table 1.96. This result means that there is a significant and positive influence between brand preference and electronic word of mouth.

This study also has similarities with Satvika's research (2013) with the research title "The Influence of Brand Personality Perceptions on Brand Preference, Brand Loyalty Attitude, and Word-Of-Mouth Behavior" which conducted research at Pizza Hut Restaurants, suggesting that consumer preferences towards Pizza Hut have a positive relationship with positive word-of-mouth behavior. Brand preference is very dependent on customer experience. In other words, positive customer experience directs customers to choose a particular brand (Hellier et al, 2003, in Satvika 2013). The attitude of consumers comes from evaluating brands after consuming certain products or services. Thus, a positive attitude towards a restaurant brand is a result of satisfaction with a particular brand of product or service, which means that there is a possibility that customers prefer certain brand products or services compared to other brands (Satvika, 2013).

\section{Hypothesis 4}

Based on the results of the analysis of brand personality variables have a positive and significant effect on electronic word of mouth through Wardah's product preference. These results are supported from the results of testing the value of $t$ count of 2.987 which is greater than the value of $t$ table 1.96. This result means that there is a significant and positive influence between brand personality and electronic word of mouth through a brand preference.

This research is in line with the research conducted by Kim et al. (2011) entitled "The effects of customers' brand personality in casual theme restaurants" which examined two restaurants said that perceptions of brand personality influence WOM behavior through mediating effects of brand preference and brand loyalty attitudes (i.e. for both restaurant chains, personality perceptions the brand displayed a causal relationship.

\section{Conclusions}

1) Brand personality directly influences positively and significantly on electronic word of mouth on Wardah products. This shows that the better the brand personality formed by the company, the better the electronic word of mouth created by Wardah consumers.

2) Brand personality directly has a positive and significant influence on brand preference on Wardah products. This shows the better the brand personality that is formed by the company, the more the brand preference arises in Wardah consumers.

3) Brand preference has a positive and significant effect on electronic word of mouth on Wardah products. This means that the better the brand preference, the more electronic word of mouth will be created by Wardah consumers.

4) Brand personality has a positive and significant effect on electronic word of mouth with brand preference as an intervening variable in Wardah products. This shows that the better the brand personality and brand preference formed by the company, the better the electronic word of mouth created by consumers

\section{References}

Aaker, Jennifer L. (1997) . "Dimensions of Brand Personality." Journal of Marketing Research. (Online). 347-356.

Aaker, D. (1995). Building Strong Brands. New York: The Free Press.

Ã, Ching-fu Chen, and Yu-ying Chang. (2008). "Airline Brand Equity, Brand Preference, and Purchase Intentions- The Moderating Effects of Switching Costs" 14: 40-42. https://doi.org/10.1016/j.jairtraman.2007.11.003. 
Anonim.(2018). “Daftar Kosmetik Bersertifikat Halal MUI Per 2018”. https://halalcorner.id/daftarkosmetik-bersertifikat-halal-mui-per-2018/. Diakses tanggal 10 Januari 2019.

Anonim. (2019). Brands. https://www.paragon-innovation.com/brands. Diakses Tanggal 25 Oktober 2018.

Badan Pusat Statistik. (2018). "Persentase Tenaga Kerja Formal Menurut Jenis Kelamin, 2015-2018". https://www.bps.go.id/dynamictable/2018/05/16/1313/persentase-tenaga-kerja-formal-menurutjenis-kelamin-2015---2017.html. Diakses tanggal 8 januari 2019.

Fimela.(2018). Rekomendasi 7 Kosmetik Lokal Berkualitas yang Harganya Bersahabat https://www.fimela.com/beauty-health/read/3814282/rekomendasi-7-kosmetik-lokalberkualitas-yang-harganya-bersahabat. Diakses 25 Oktober 2018.

Hellier, Phillip K., Gus M. Geursen, Rodney A. Carr, and John A. Rickard. (2003). 37 European Journal of Marketing Customer Repurchase Intention. http://www.emeraldinsight.com/doi/10.1108/03090560310495456.

Hennig-Thurau, Thorsten, Kevin P. Gwinner, Gianfranco Walsh, and Dwayne D. Gremler. (2004). "Electronic Word-of-Mouth via Consumer-Opinion Platforms: What Motivates Consumers to Articulate Themselves on the Internet?" Journal of Interactive Marketing 18(1): 38-52.

Japutra, Arnold, and Sebastian Molinillo. (2017). "Responsible and Active Brand Personality: On the Relationships with Brand Experience and Key Relationship Constructs." Journal of Business Research (November 2016): 0-1. http://dx.doi.org/10.1016/j.jbusres.2017.08.027.

Ihsan, Maftuh.2018. "Industri Kosmetik Diperkiran Tumbuh 7,33\% Tahun ini". https://www.google.com/amp/s/m.bisnis.com/amp/read/20180716/817224/industri-kosmetikdiperkirakan/tumbuh/733-tahun-ini. Diakses tanggal 21 desember 2018.

Kim, Dohee, Vincent P. Magnini, and Manisha Singal. (2011). "The Effects of Customers' Perceptions of Brand Personality in Casual Theme Restaurants." International Journal of Hospitality Management 30(2): 448-58. http://dx.doi.org/10.1016/j.ijhm.2010.09.008.

Rangkuti, Fredy. (2004). The Power of Brand. Jakarta: PT. Gramedia Pustaka Utama

Satvika, Audrie Diandra. (2013). "Pengaruh persepsi kepribadian merek terhadappreferensimerek, sikap loyalitasmerek, danperilakuwom (studi kasus: restoran pizza hut)". FE UI

Schiffman, Leon G. Leslie, Lazar Kanuk. (2004). "Perilaku Kosumen". Alih Bahasa Oleh Zoelkifli Kasip. Edisi Ketujuh. Jakarta: Indeks Gramedia.

Su, Lujun, Scott R Swanson, Sydney Chinchanachokchai, Maxwell K Hsu, and Xiaohong Chen. (2016). "Reputation and Intentions: The Role of Satisfaction, Identi Fi Cation, and Commitment."Journal of Business Research. https://doi.org/10.1016/j.jbusres.2016.02.023.

Tanjung, Juhan. (2013). "Pengaruh harga, citra merek, dan personalitas merek terhadap preferensi merek pada laptop Hewllet Packard (Hp)". Surabaya: STIE Perbanas

Upamannyu, Nischay Kumar, Garima Mathur, and S.S Bhakar. (2014). "The Connection between Self Concept (Actual Self Congruence \&amp; Ideal Self Congruence) on Brand Preferences." International Journal of Management Excellence 3(1): 308. http://www.ijmeonline.com/index.php/ijme/article/view/126.

Wahyuningtyas, Ida. (2015). "Pengaruh Brand Love Dan Brand Personality Serta Brand Image Terhadap Word of Mouth Fashion Sophie Paris Pada Mahasiswa Fakultas Ekonomi Dan Bisnis Universitas Jember." : 1-92 